\title{
MONITORING TARGET HEART RATE (THR) UNTUK OPTIMALISASI LATIHAN LARI BERBASIS INTERNET OF THINGS
}

\author{
Musayyanah ${ }^{1}$, Ira Puspasari ${ }^{2}$, Pauladie Susanto ${ }^{3}$ \\ Sistem Komputer, Fakultas Teknologi dan Informatika \\ Institut Bisnis dan Informatika Stikom Surabaya, Indonesia \\ e-mail : ${ }^{1}$ musayyanah@stikom.edu, ${ }^{2}$ ira@stikom.edu, ${ }^{3}$ pauladie@stikom.edu
}

Diterima: 30 September 2018. Disetujui : 19 Oktober 2018. Dipublikasikan : 10 Desember 2018

(C)2018 -TESJ Fakultas Teknik Universitas Maarif Hasyim Latif. Ini adalah artikel dengan

akses terbuka di bawah lisensi CC BY 4.0 (https://creativecommons.org/licenses/by/4.0/)

\begin{abstract}
ABSTRAK
Olahraga merupakan salah satu aktifitas rutin yang dilakukan oleh masyrakat, seperti olahraga yang melatih kardio atau denyut jantung. Kategori olahraga yang mudah dilakukan oleh masyarakat adalah olahraga lari, yang tidak membutuhkan teknik yang rumit dan tidak butuh biaya mahal untuk melakukannya. Aktifitas lari ini sangat mempengaruhi kondisi jantung, khususnya bagi pelari pemula dan atlit lari. Jika olahraga ini, tidak dipantau dengan baik oleh Pelatih atau Personal Trainer, maka mengakibatkan kematian. Sistem Monitoring yang mengintegrasikan hardware dengan software diterapkan untuk memudahkan proses monitoring. Pantauan yang dilakukan untuk nilai THR (Target Heart Rate) dengan menerapkan metode Karvonen. Integrasi hardware yang meliputi sensor Grove Finger ClipHeart Rate, Modul Transmisi Wireless (Modul ESP 8266) dan Arduino. Performansi 0,6\% untuk tingkat kesalahan sensor dan kemampuan transmisi data dengan paket loss $<1 \%$ untuk modul ESP. Hardware Monitoring tersebut terintegrasi baik dengan aplikasi monitoring lewat jaringan lokal dan akses web lewat jaringan internet.
\end{abstract}

Kata kunci:heart rate, karvonen, lari, personal trainer, sistem monitoring, internet of things

\section{PENDAHULUAN}

Olahraga saat ini menjadi kebutuhan utama bagi masyrakat, dimana olahraga tersebut, terbagi menjadi 3 kategori yaitu Olahraga kategori 1, kategori 2, dan kategori 3. Olahraga kategori 1 tidak memerlukan ketrampilan khusus dan denyut nadi mudah diukur, Olahraga kategori 2 merupakan olahraga yang memerlukan ketrampilan dan denyut nadi sulit diukur, sedangkan kategori 3 adalah olahraga permainan dan denyut nadi sangat sulit diukur, misalnya tenis, basket, bulu tangkis. Berbagai tipe dari olahraga mulai diikuti oleh masyarakat, selain bermanfaat bagi kesehatan, masyarakat sudah mulai menerapkan olahraga sebagai gaya hidup atau bahkan rutinitas sehari-hari.

Olahraga yang mudah dilakukan oleh banyak orang adalah olahraga lari. Lari adalah salah satu aktifitas fisik yang membutuhkan banyak energi, yang dapat meningkatkan denyut jantung. Lari merupakan latihan kardio yang efektif membakar kalori. Teknik melakukanya sangat mudah dan tidak membutuhkan biaya tinggi untuk melakukannya, terutama bagi pemula yang membutuhkan pemantauan atau monitoring. Selain itu, terdapat sebuah kasus dimana seorang atlit lari mengalami serangan jantung tiba-tiba hingga menyebabkan kematian, ketika sedang melakukan aktifitas lari tahun 2013 di ajang Jakarta Marathon(Febrida, 2013), hal ini disebabkan olehdenyut jantung atlit tersebut melebihi Heart Rate Maksimal. Sehingga, pemantau Heart Rate (HR) dibutuhkan untuk memastikan kegiatan lari dapat dikontrol oleh Personal Trainer atau Pelatih.

Pantauan terhadap Heart Rate atau dikenal dengan istilah HRM (Heart RateMonitors) merupakan salah satu parameter untuk menentukan tingkat daya ketahanan tubuh olahragawan (endurance training). Heart Rate juga menentukan besarnya intensitas olahraga yang dilakukan (Achten, 2003). Intensitas tersebut sangat berpengaruh terhadap kesehatan jantung bagi yang melakukan olahraga, sehingga diperlukan sebuah metode untuk memantau kondisi HR dengan intensitas aktifitas yang dilakukan. Hubungan HR dan intensitas aktifitas olahraga disebut dengan Target Heart Rate (THR).

THR adalah nilai Heart Rate yang ingin dicapai selama latihan kardio yang memungkinkan jantung dan paru-paru menerima manfaat dari banyak latihan kardio yang dilakukan. THR ini bergantung pada kondisi fisik seseorang, jenis kelamin dan intensitas latihan yang dilakukan. Intensitas tersebut dibagi menjadi beberapa kategori yaitu : Intensitas dengan batas 50-60\% 
berada pada Zona Moderate-Intensity, intensitas ini bisa tercapai cukup dengan jalan kaki. Intensitas dengan nilai 60-70\%, yang berada pada Zona Moderate-Intensity-Exercesis seperti jogging.

Untuk mendapatkan nilai THR terdapat beberapa metode yang telah diterapkan, seperti metode Karvonen, metode Tanaka , dan Threshold Velontory. Pada (Camarda, 2008) telah membuktikan bahwa metode Karvonen dan Tanaka merupakan metode dengan tingkat akurasi yang hampir sama. Namun American College and Sport Medicine (ACSM) menetapkan metode Karvonen sebagaistandart pengukuran THR untuk segala bentuk aktifitas olahraga.(Wilkins, 2000)

Perhitungan THR yang berbasis metode Karvonen telah dilakukan pada (Puspasari, Musayyanah, \& Susanto, 2018), yang merancang Prototype untuk deteksi HR, berupa notifikasi sms, dimana sms tersebut berisi pemberitahuan mengenai kegiatan aktifitas serta warning THR melebihi batas. Hasil penelitian tersebut, masih memiliki kekurangan yaitu data HR dari atlit tidak bisa diakses secara real time, melainkan hanya lewat notifikasi dari sms. Sebagai penyempurnaan dari penelitian tersebut, maka jurnal ini memberikan kontribusi dengan membuat prototype berupa "wearable device" untuk atlit, dimana HR tersebut dapat diakses secara online dan real time.

Prototype yang menyerupai Wearable device, untuk mendeteksi HR di bidang medis telah banyak diciptakan seperti pada (Harsono, Liman, \& Djohan, 2017) yang menggunakan metode photoplethysmography (PPG). Hal yang sama, telah dilakukan oleh (Yulian \& Suprianto, 2017) dengan mendesain Prototype sensor yang berbasis Arduino, dengan penambahan rangkaian bandpass. Dimana, pembuatan prototype tersebut masih memiliki kesalahan dalam pembacaan HR. Maka pada penelitian ini menggunakan metode PPG dengan sensor Grove Finger Clipyang berbasis cahaya led.

Prototype untuk deteksi data HR hanya terbatas pada akses individu, atau akses jarak dekat, sehingga pada jurnal ini membuat prototype data HR untuk diakses pada jarak jauh sesuai dengan teknologi IoT (Internet of Things) dimana nantinya data HR tersebut bisa diakses secara bersamaan, pada waktu yang sama, dan pada lokasi jarak jauh. (Islam, Kwak, Kabir, Hossain, \& Kwak, 2015).

\section{METODE PENELITIAN}

Metode penelitian untuk monitoring HR padapenelitian ini terdiri dari: Perancangan PrototypeMonitoring HR; dan Sistem Transmisi Data HR Berbasis IoT.

\section{Perancangan Prototype Monitoring HR}

Perancangan Hardware yang terdiri dari mikrokontroller dan beberapa komponen input dan output seperti sensor Grove Finger Clip HR, Modul ESP, dan baterai rangkaian step up. Berikut pin-pin dari mikrokontroler (Arduino) yang terhubung ke sensor Grove Finger Clip dan Modul ESP.

\begin{tabular}{c|c} 
Tabel 1. Penggunaan Pin-Pin Arduino \\
\cline { 2 - 2 } No Pin & Terhubung dengan \\
\hline SCL 21 & SCL Sensor \\
SDA 22 & SDA I2C Sensor \\
2 RX & TX ESP 8266 \\
3 TX & RX ESP 8266 \\
3,3V & VCC Sensor \\
\hline
\end{tabular}

Penggunaan Tabel 1, disusun dalam satu PCB yang kemudian dikemas ke dalam box yang telah didesain sesuai dengan kebutuhan. Box tersebut diberi nama Box Monitoring HR.

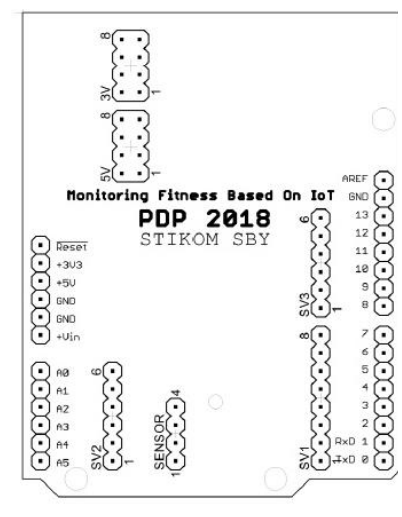

(a)

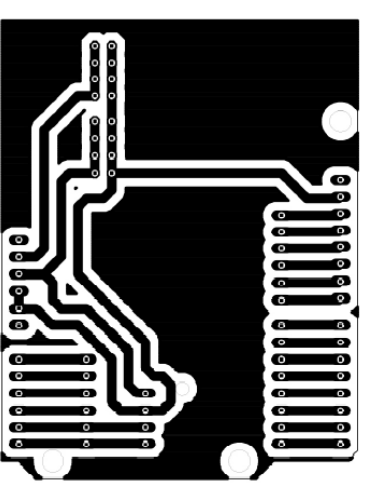

(b)
Gambar 1. PCB : (a) Tampak Depan; (b) Tampak Belakang

Gambar 1 PCB, menghubungkan arduino dengan sensor dan modul ESP, dimana arduino yang digunakan adalah arduino rev 3 yang digunakan sebagai pembacaan nilai HR darisensor GroveFinger Clip Heart Rate, dan transmisi data HR menggunakan ESP 8266. Selain itu, terdapat sumber tegangan input dalam bentuk bateraiyang ditambahkan rangkaian step-up(penaik tegangan).

Ukuran PCB, menyesuaikan dengan ukuran BOX Monitoring HR. dimana Box Monitoring HR didesain kotak dengan tujuan dapat menyerupai wearable device, yang dipasangkan di lengan Sampel. Desain dari Box tersebut, ditunjukkan pada Gambar 2.

Desain Box Monitoring HR berbentuk kotak dengan tutup, yang nantinya modul transmisi berada di dalam Box tersebut, sedangkan sensor berada di luar Box, dilekatkan pada jari telunjuk sampel. Posisi Box Monitoring HR dilekatkan di lengan kanan atau kiri dari sampel. Posisi letak dari Box tersebut dicontohkan pada Gambar 3. 


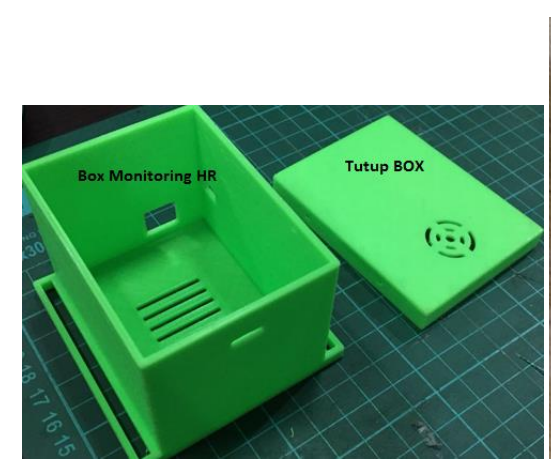

(a)

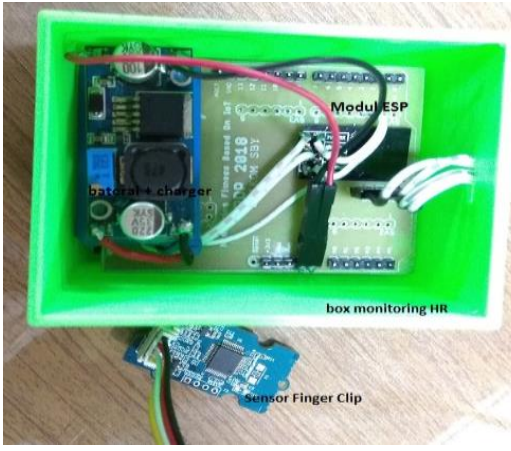

(b)

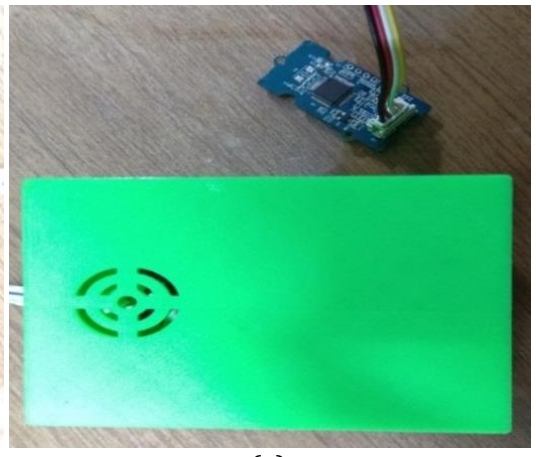

(c)

Gambar 2.(a) Tampak Luar-Dalam Box Monitoring HR;

(b) Box Monitoring HR dengan Rangkaian Komponen;

(c) Box Monitoring HR Tertutup

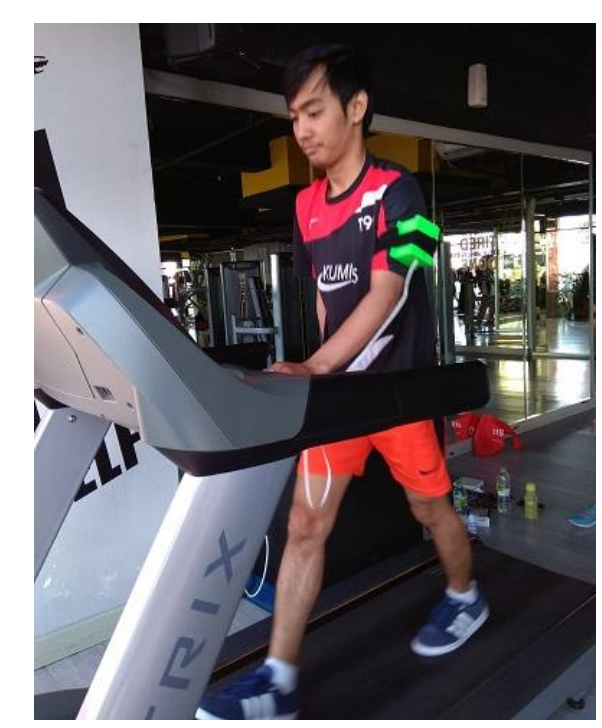

Gambar 3. Posisi Box Monitoring Pada Sampel

\section{Sistem Transmisi Data HR Berbasis IoT}

Sistem Transmisi Data ditunjukkan pada Gambar 4.
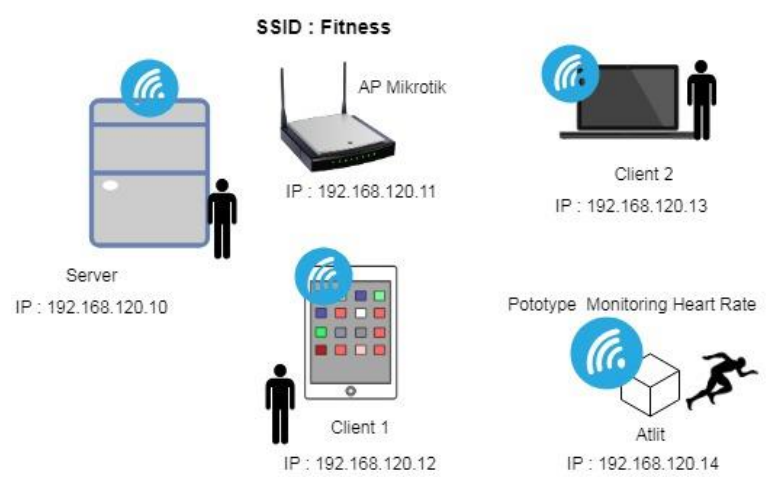

Gambar 4. Sistem Komunikasi Monitoring HR

Sistem komunikasi pada Gambar 4 merupakan sistem komunikasi multipoint, dengan pengirim adalah Prototype yang dipakai oleh atlit untuk membaca data Heart Rate, yang nantinya data tersebut akan diterima oleh server dan Client yang lain, mengakses data HR tersebut lewat gadget aplikasi monitoring atau web.
Atlit Lari dalam hal ini diujicobakan pada sampel yang sedang melakukan aktifitas jogging di atas treadmill, berikut langkah-langkah Prototype terhubung dengan server dan Client:

1. Hardware terhubung dengan Router(SSID: Fitness)

2. Server merupakan database HR dari masingmasing sampel, dimana pada Server ini akan berisi identitas diri dari sampel seperti usia, umur, dan batas THR maksimal. Server terhubung dengan wifi, SSID : Fitness. Identitas sampel diinputkan manual ke PC Server.

3. Gadget yang sudah terinstall aplikasi monitoring terhubung pula pada SSID: Fitness

4. Client dapat mengakses data HR tersebut lewat web yang sudah terhubung dengan internet.

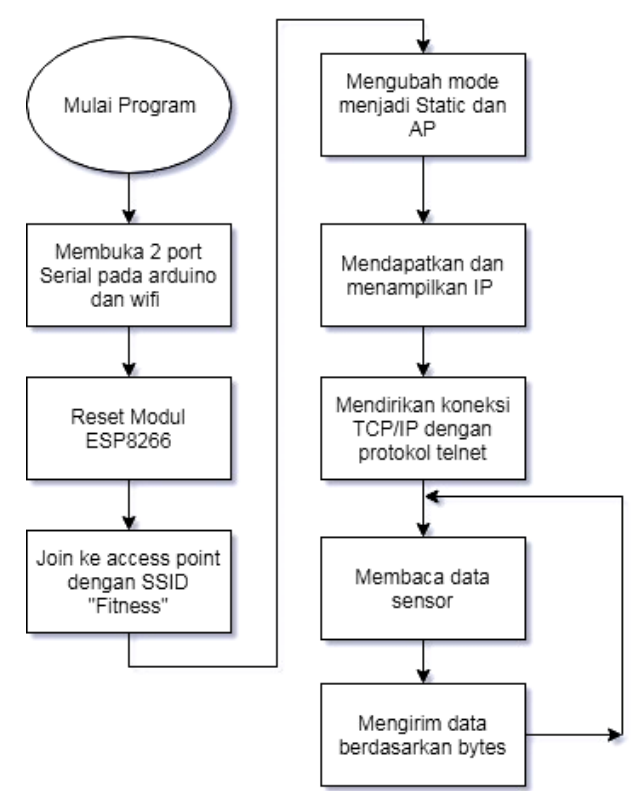

Gambar 5. Proses Koneksi Hardware ke Jairngan Fitness

Hardware yang terhubung dengan Router masih menggunakan jaringan lokal dengan SSID : Fitness, dengan memanfaatkan arduino dan modul ESP, maka proses koneksinya ditunjukkan pada Gambar 5. Setelah terhubung dengan SSID : Fitness, maka langkah berikutnya adalah Server 
menyimpan data dari sampel untuk perhitungan HR menggunakan metode Karvonen, yang ditunjukkan pada persamaan (1). Data input dari sampel berupa ID, Nama, Usia, Gender, HR maksimal, dan Rest Heart Rate, yang akan diinputkan oleh Admin .

Diagram Alir untuk menampilkan GUI pada pemograman pada sisi Server ditunjukkan pada Gambar 6, serta tampilan GUI dari inputan data tersebut. Pada Gambar 7, perhitungan THR menggunakan metode Karvonen sesuai dengan persamaan (1).

$$
\begin{aligned}
& T H R=\left\{\left(H R_{\max }-R H R\right) \times \text { Intensitas }\right\}+R H R \\
& H R_{\max }(\text { wanita })=206-(0.88 \times \text { Usia }) \\
& H R_{\max }(\text { laki-laki })=206.9-(0.67 \times \text { Usia })
\end{aligned}
$$

dengan :

Intensitas : 70\% untuk aktifitas jogging

RHR : RestHeart Rate (detak jantung dalam kondisi tenang)

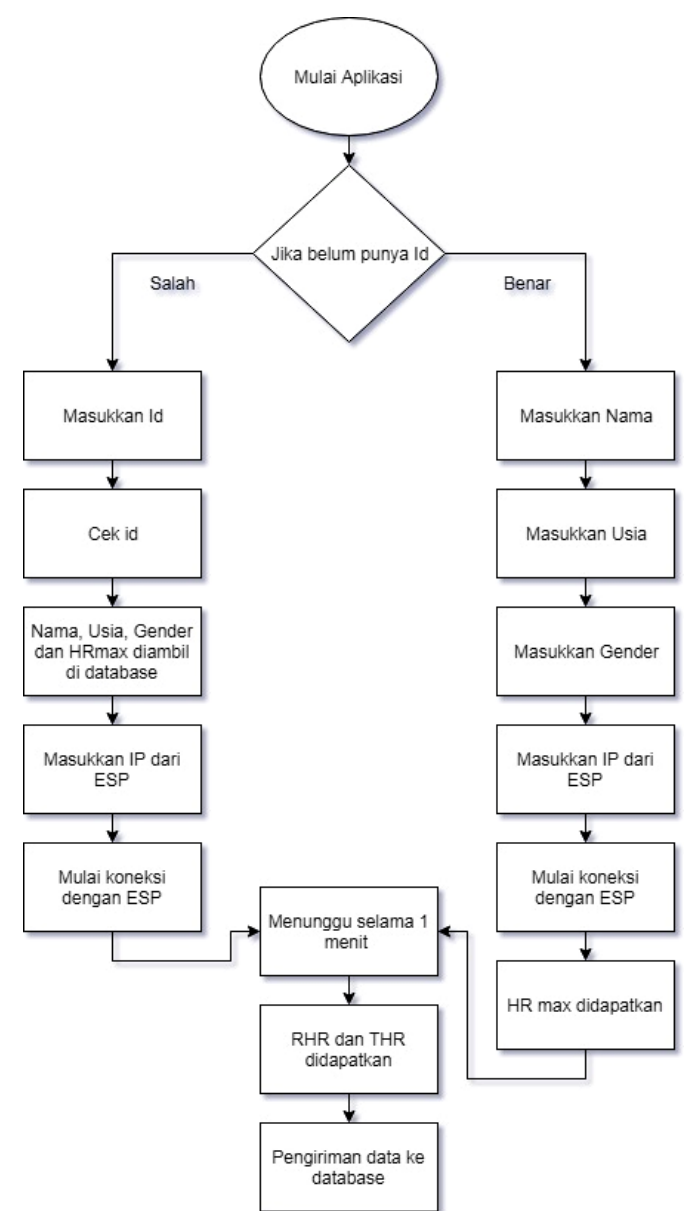

Gambar 6. Diagram Alir Koneksi Server ke ESP dan Database

Tampilan GUI dari sisi Server, ketika menginputkan data sampel ditunjukkan pada Gambar 7. Tampilan tersebut, merupakan salah satu eksekusi program pada diagram alir Gambar 6, Admin Server akan menginputkan data dari sampel, yang kemudian data tersebut akan tersimpan di dalam database. Setelah disimpan di database, maka secara bersamaan data HR pada gadget dan pada web dapat diakses secara bersamaan. Teknik menjalankan aplikasi gadget tersebut ditunjukkan pada Gambar 8.

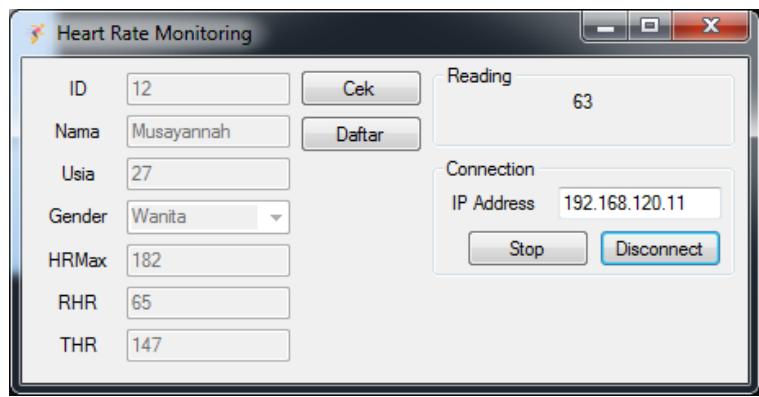

Gambar 7. GUI Inputan Data Sampel

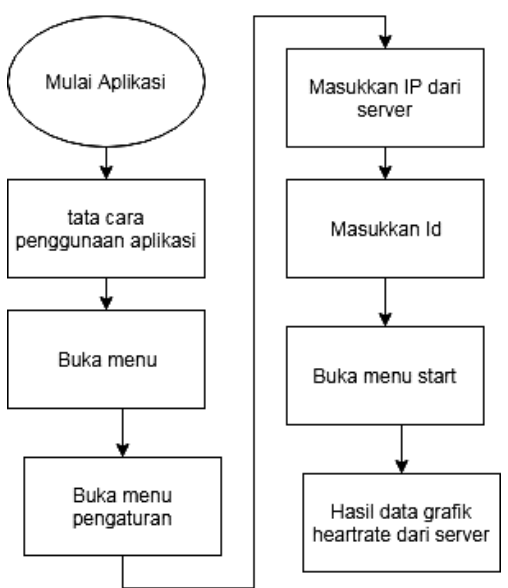

Gambar 8. Diagram Alir Aplikasi Monitoring

Aplikasi yang telah dibuat dan terinstall pada gadget, ditunjukkan pada Gambar 9.

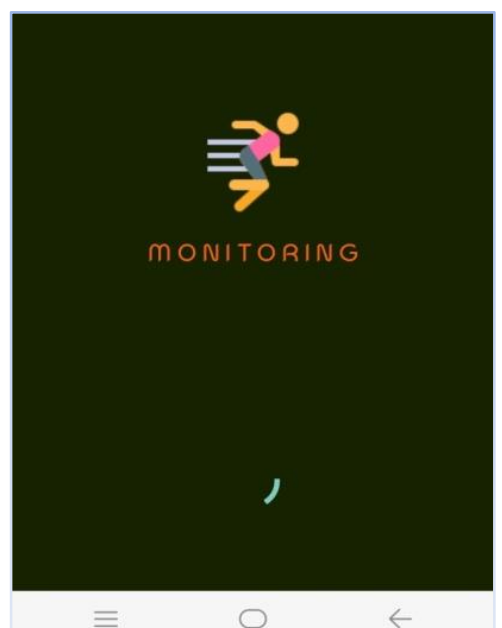

Gambar 9. Tampilan Awal Aplikasi Monitoring

Apabila telah melakukan pengaturan untuk aplikasi terkoneksi dengan SSID: Fitness, maka hasil monitoring dengan aplikasi ditunjukkan pada Gambar 10(b). 


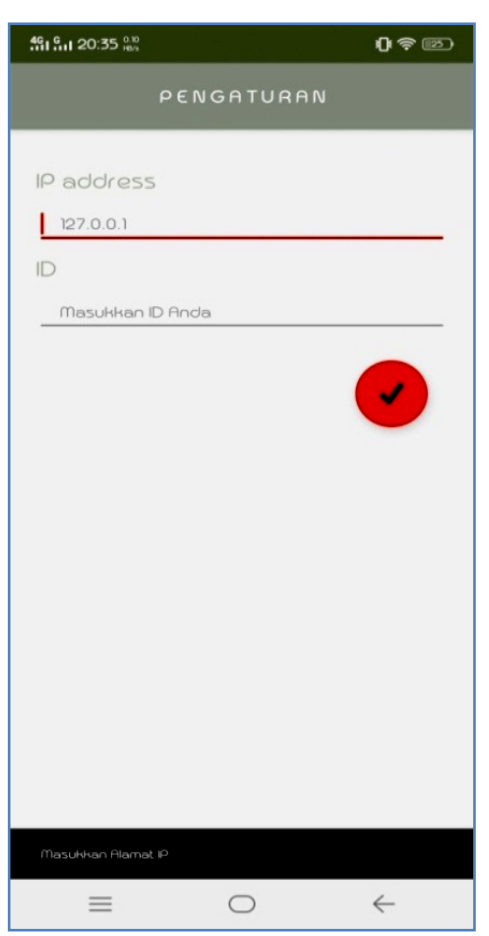

(a)

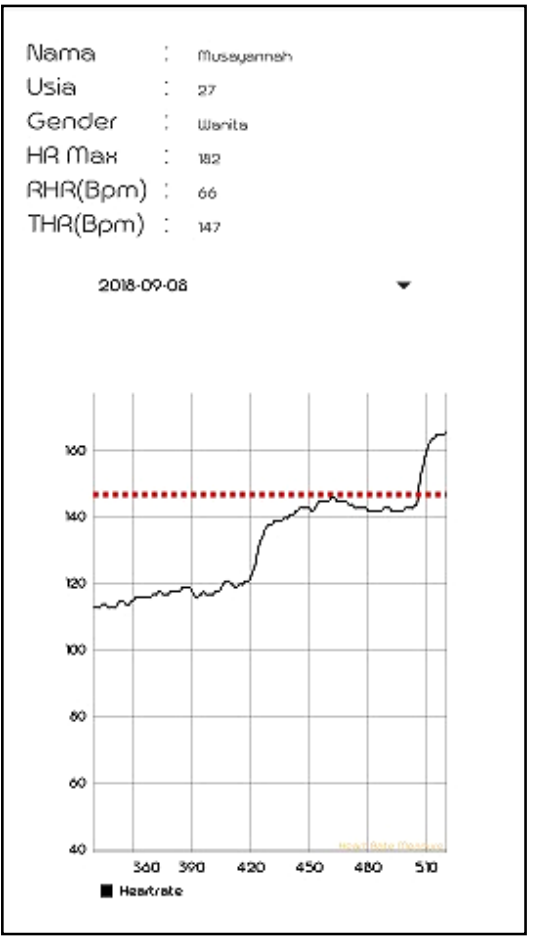

(b)

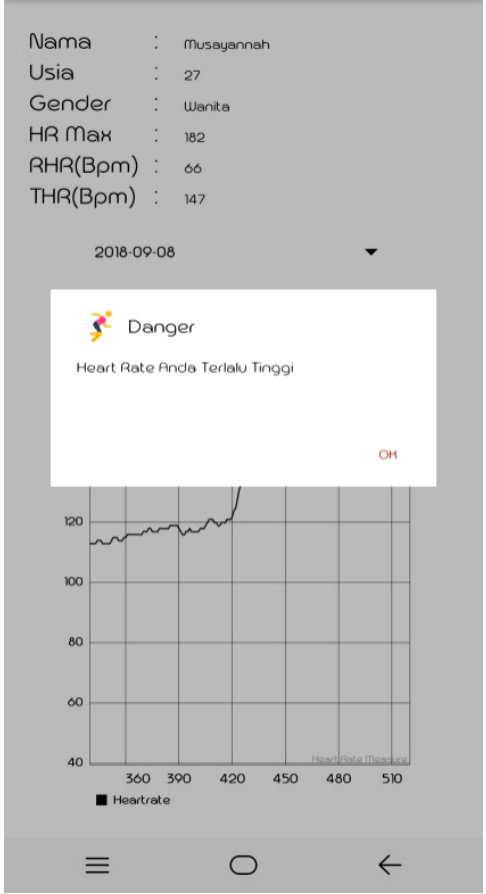

(c)

Gambar 10. Tampilan aplikasi : (a) Halaman Pengaturan;

Berdasarkan tampilan Aplikasi tersebut, dapat dilihat bahwa aktifititas melebihi THR yang ditunjukkan dengan data HR sedang aktifitas, melewati garis merah threshold (THR), sehingga diwajibkan berhenti untuk menjaga kesehatan denyut jantung. Di mana kewajiban berhenti tersebut ditunjukkan dengan adanya alarm seperti Gambar 10(c). Alarm yang berbunyi dengan tampilan notifikasi pemberitahuan bahwa "HR anda Terlalu Tinggi“. Aplikasi ini dapat digunakan oleh Pemantau atau Personil Trainer /Pelatih dan orang-orang terdekat.

Hasil Warning tersebut dapat dipantau pula menggunakan web browserdengan alamat : http://fitness-pdp2018stikomsby.com, akses alamat web tersebut lewat jaringan publik atau internet, maka hasil pantauan $\mathrm{HR}$ bisa dilihat secara real time.

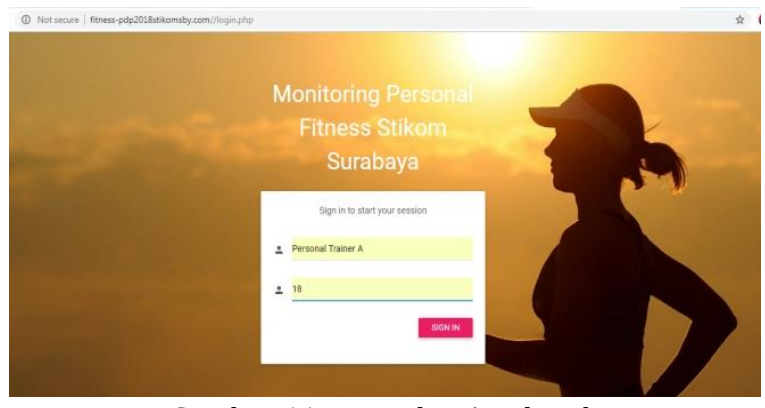

Gambar 11. Tampilan Awal Web

Tampilan awal dari web, menunjukkan proses login dari Personal Trainer (PT) untuk setiap ID Atlit yang berbeda-beda, sehingga hal ini memudahkan PT, untuk memantau kondisi masing-masing atlit. b) Hasil Monitoring HR; (c) Warning THR melebihi Batas

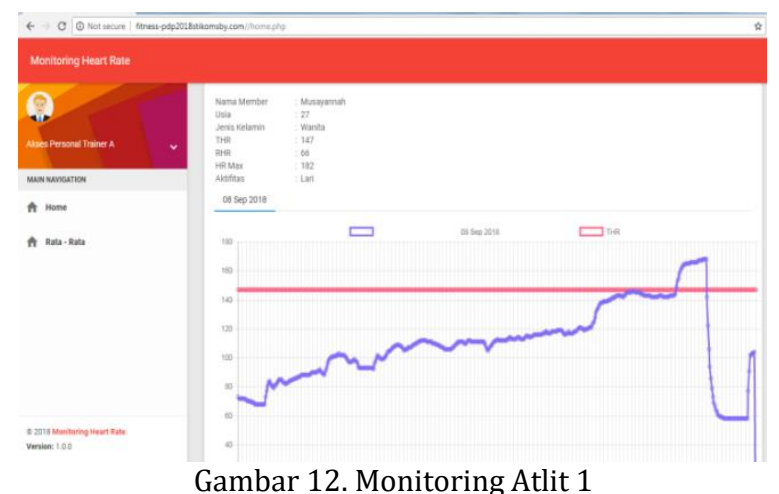

Setelah PT berhasil log in dengan id member, maka PT bisa memantau rutinitas langsung dari atlit, dimulai dari identitas atlit, kondisisi HR setiap latihan, dan nilai THR. Kondisi HR tersebut apabila melebihi THR, maka akan muncul warning pula di setiap laporan kegiatan perhari dari aktifitas yang dilakukan.

\section{HASIL DAN PEMBAHASAN}

Hasil dan pembahasan ditinjau dari : (1) kinerja Prototype yang telah dibuat, seperti kinerja sensor Grove Finger Clip; (2) kinerja modul ESP dalam Box Monitoring; (3) kinerja Sistem IoT dari akses lokal hingga akses internet lewat web.

\section{Analisis Kinerja Sensor Grove Finger-CLip}

Analisis kinerja sensor adalah membandingkan sensor Gover Finger Clip dalam mendeteksi HR dengan sensor yang akurat standar 
rumah sakit seperti Oxymeter. Pada Gambar 13 memperlihatkan cara membandingkan kinerja dari kedua sensor tersebut.

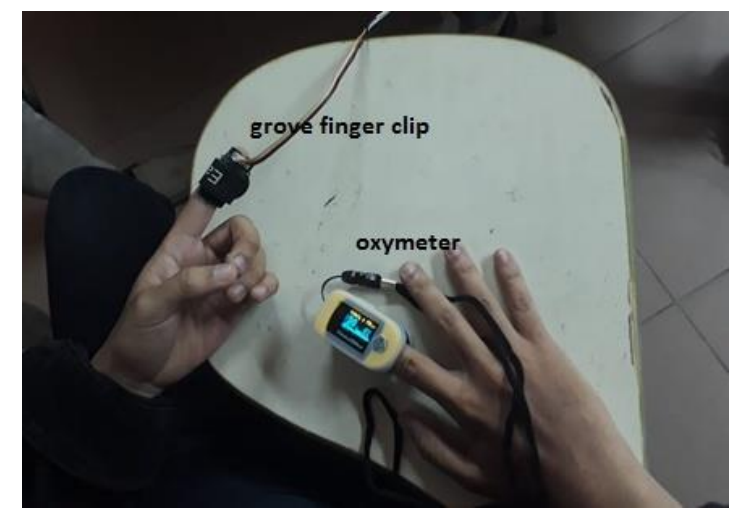

Gambar 13. Sensor Grove-Oxymeter

Tabel 2 Kinerja Sensor Grove-Oxymeter

\begin{tabular}{cccccc}
\hline No & $\begin{array}{c}\text { Sampel/ } \\
\text { gender }\end{array}$ & $\begin{array}{c}\text { Umur } \\
\text { (tahun) }\end{array}$ & $\begin{array}{c}\text { Oxymeter } \\
\text { (bpm) }\end{array}$ & $\begin{array}{c}\text { Sensor Grove } \\
(\mathrm{bpm})\end{array}$ & $\begin{array}{c}\text { Error } \\
(\%)\end{array}$ \\
\hline 1 & A (L) & 21 & 98 & 98 & 0 \\
2 & B (L) & 21 & 82 & 83 & 1 \\
3 & C (L) & 22 & 85 & 86 & 1 \\
4 & D (L) & 45 & 78 & 78 & 0 \\
5 & E (W) & 27 & 71 & 72 & 1 \\
& & & & & \\
\hline
\end{tabular}

Berdasarkan Tabel 2, kinerja dari sensor Grove Finger Clip cukup baik, jika dibandingkan dengan Oxymeter, dimana rata-rata kesalahannya hanya $0.6 \%$. Sampel yang diujikan sebanyak 5 sampel dengan 4 laki-laki dengan 1 wanita, dengan umur yang berbeda.

\section{Analisis Kinerja Modul ESP 8266 pada Box Monitoring HR}

Pengujian kinerja modul ESP yang tersimpan di dalam Box Monitoring HR, dilakukan dengan beberapa skenario pengambilan data, yaitu pengambilan data LOS (Line of Sight) dan pengambilan data multi obstacle (penghalang). Pengujian ini memastikan kinerja dari modul yang terletak di dalam kotak. Berikut hasil dari pengujiannya.

\section{Pengujian Skenario 1}

Pengujian Skenario 1, dilakukan di lapangan Arena Prestasi Stikom, yang ditunjukkan pada denah Gambar 14. Denah Skenario 1 terdapat Admin Server sekaligus penerima data HR, yang menerima data HR dari prototype yang digunakan oleh Atlit Lari (Runner). Pada saat yang bersamaan, Client mengakses data HR tersebut lewat aplikasi fitness di gadget. Pengujian ini mengukur Paket Loss dari proses pengujian LOS (tanpa penghalang) dan dengan penghalang (tembok). Di mana pengujian ini, dilakukan dengan mengubah jarak dari pengirim (Atlit) ke Penerima (Server).

Pada Tabel 3, menunjukkan kinerja dari modul ESP yang terletak di dalam Box Monitoring HR. Dimana modul ESP masih bisa mentrans- misikan data HR dengan baik pada kondisi LOS (tanpa penghalang) dan pada kondisi dengan penghalang. Definisi dari Penghalang adalah terdapat sebuah pilar tembok dan beberapa penghalang pintu yang tertutup dengan plastik. Prosentasi dari Paket Loss yang terjadi masih di bawah angka $1 \%$, hal ini menunjukkan bahwa modul ESP masih bisa meng-cover proses transmisi data HR dengan baik pada posisi di dalam Box Monitoring HR.

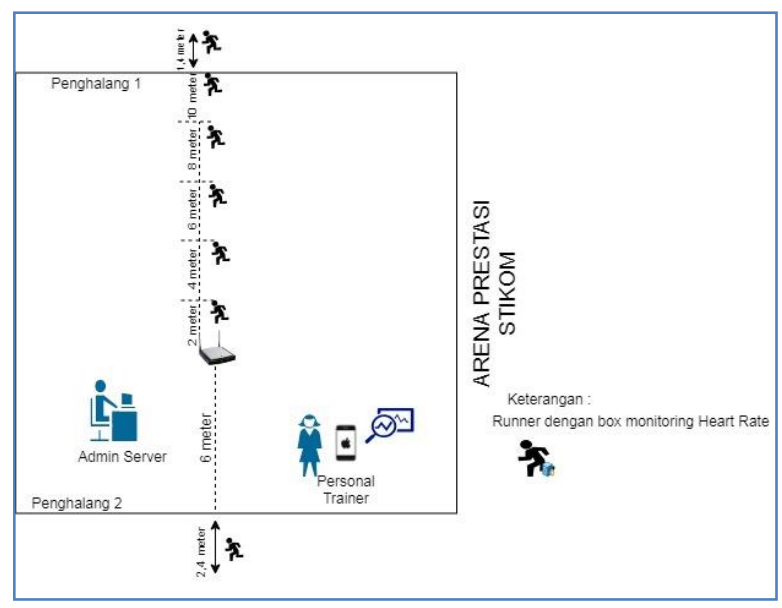

Gambar 14. Denah Skenario 1

Tabel 3. Paket Loss Skenario 1

\begin{tabular}{cccc}
\hline $\begin{array}{c}\text { Jarak } \\
(\mathrm{m})\end{array}$ & $\begin{array}{c}\text { Packet Loss } \\
\text { (Bytes) }\end{array}$ & $\begin{array}{c}\text { Data Kirim } \\
\text { (Bytes) }\end{array}$ & $\begin{array}{c}\text { Packet Loss } \\
(\%)\end{array}$ \\
\hline 2 & 16 & 10728 & 0.15 \\
4 & 12 & 10728 & 0.11 \\
6 & 12 & 10728 & 0.11 \\
8 & 16 & 10728 & 0.15 \\
8,4 & 32 & 10728 & 0.30 \\
10 & 16 & 10728 & 0.15 \\
14,9 & 32 & 10728 & 0.30 \\
\hline
\end{tabular}

\section{Pengujian Skenario 2}

Pengujian Skenario 2 masih menguji kinerja dari media tranmisi dengan lokasi yang berbeda, lokasi ini merupakan lokasi yang bersekat-sekat dengan penghalang kayu dan kaca, serta terdapat pilar tombok yang besar, Lokasi dilakukan di Lantai 3 Ruang dosen Stikom Surabaya Seperti yang ditunjukkan pada denah lokasi skenario Gambar 15.

Berdasarkan Denah Skenario 2, Posisi 1,2, dan 3 merupakan Node Pengukuran antara pemancar dan penerima yang terpisah dengan jarak tertentu dan berpenghalang. hasil pengiriman data ditunjukkan pada Tabel 4. Berdasarkan Tabel 4, menunjukkan bahwa Paket Loss dengan jarak terjauh yang memiliki nilai Loss yang besar, sedangkan pada denah, jarak 14 meter ditunjukkan pada node 3 , node tersebut merupakan jarak terjauh dan penghalang berupa sekat dan pilar, sehingga memungkinkan untuk terjadi loss pada posisi tersebut. 


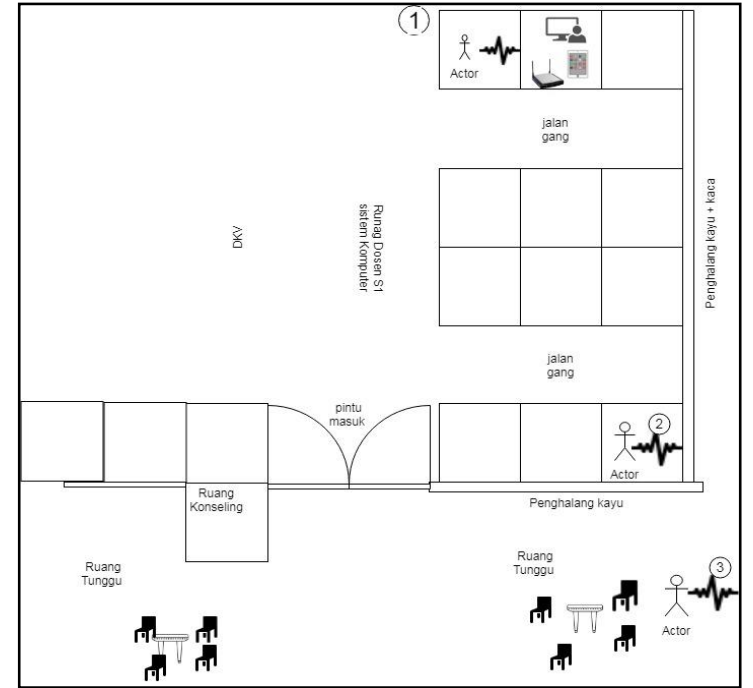

Gambar 15. Denah Skenario 2

Tabel 4. Paket Loss pada Skenario 2

\begin{tabular}{cc}
\hline Jarak (meter) & Packet Loss (Bytes) \\
\hline 1 & 0 \\
6 & 0 \\
11 & 112 \\
14 & 176 \\
\hline
\end{tabular}

\section{Pengujian Hardware dan Sistem pada Aktifitas} Jogging Treadmill

Pengujian ini mengintegrasikan antara hardware yang telah dibuat dengan sistem komunikasi yang dirancang, serta integrasi aplikasi dan web yang telah dibuat. Aktifitas ini dilakukan di tempat fitness Urban Gunawangsa dengan melibatkan beberapa Sampel. Aktifitas Jogging yang dilakukan oleh setiap sampel memiliki kecepatan yang berbeda-beda, dimana kecapatan langkah diatur di treadmill, Selama beberapa menit sampel melakukan aktifitas yang dimulai dari jalan pelan, jalan cepat hingga jogging, Selamat Aktifitas tersebut, HR ter-record oleh sistem, dan akan terdapat sebuah peringatan apabila nilai HR melebihi nilai THR.

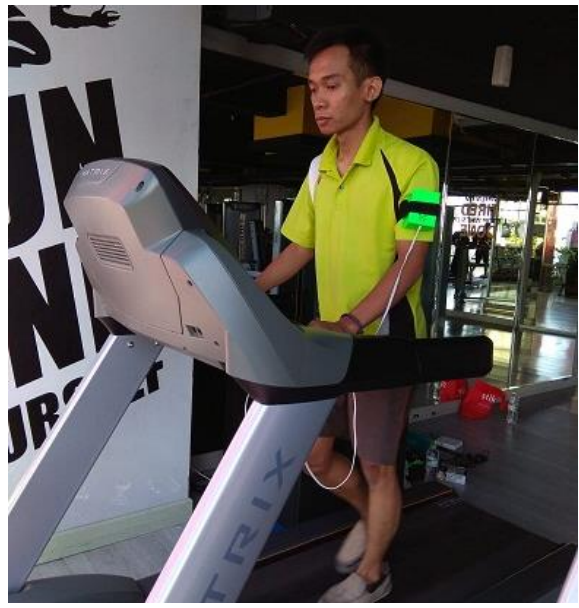

Gambar 16. Sampel 2 Beraktfiitas Jogging

Pada Gambar 16, sampel 2 melakukan aktifitas di atas treadmill selama 19 menit untuk mencapai batas THR 160 bpm. Kecepatan yang sampel gunakan dimulai dari $4 \mathrm{mph}$ dengan jalan santai, dilanjutkan jalan cepat dengan kecepatan 5,5 mph sampai $8 \mathrm{mph}$ untuk lari. Sehingga untuk mendapatkan nilai batas maksimal tidak membutuhkan waktu yang lama. Pada tampilan Smart phone terlihat bahwa data yang terbaca pada smart phone PT stabil, dimana HR yang terekam stabil naik sampai mencapai batas THR. Hasil data yang terekam ditunjukkan pada Gambar 17.

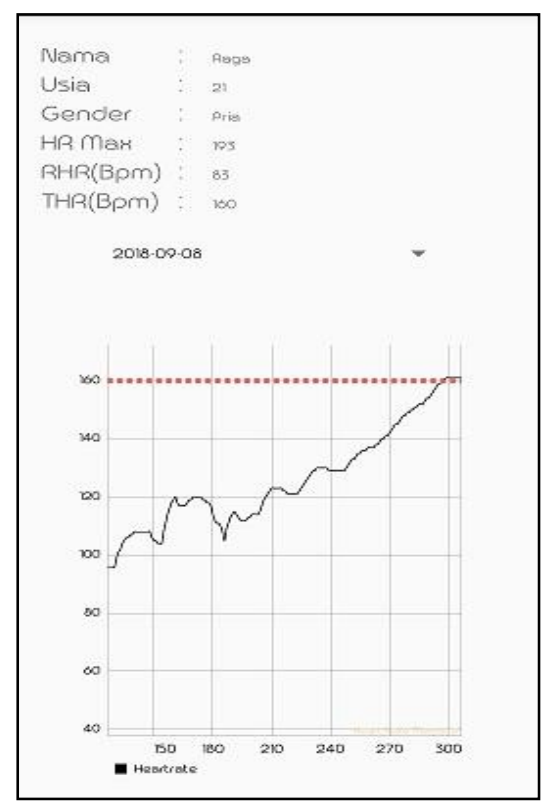

Gambar 17. Hasil Monitoring Sampel 2 pada gadget

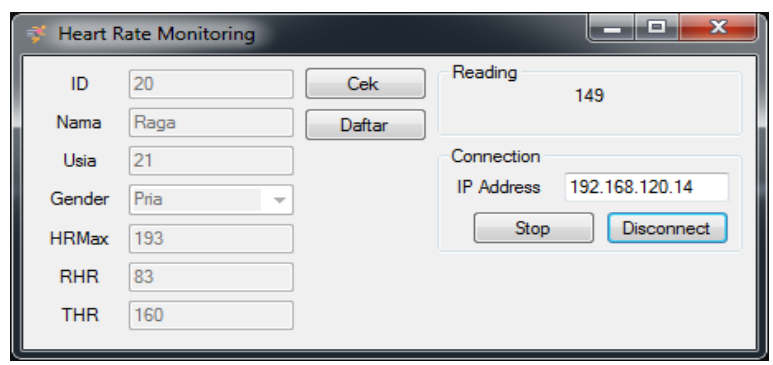

Gambar 18. Data Sampel 2 pada Server

Berdasarkan data Sampel 2 jenis kelamin laki-laki usia 21 tahun, batas nilai THR $=160 \mathrm{bpm}$. Aktifitas yang bisa dilakukan oleh sampel 2, tidak boleh melebihi batas THR. Hardware yang digunakan oleh Sampel 2 ketika beraktifitas, masih bisa mendeteksi HR dengan baik yang ditunjukkan dengan tampilan grafik aplikasi.

\section{PENUTUP}

Monitoring Atlit Lari menggunakan prototype dalam bentuk Box Monitoring HR, yang dikirimkan ke dalam database server, dan dipantau secara real time di aplikasi dan web browser, memiliki beberapa penilaian performansi atau kinerja dari prototype tersebut, yang meliputi 
tingkat kesalahan sensor mencapai $0.6 \mathrm{HR} \%$ dan kinerja media tranmisi (modul ESP) mampu mengirimkan data HR secara real time dengan loss $<1 \%$.

Penelitian ini masih menyimpan data HR yang berasal dari hardware pada database lokal, yang kemudian data tersebut diupload secara manual ke cloud atau database hosting, sehingga akses real time pada web masih perlu diperbaiki. Selain itu, desain dari prototype perlu dieksplore lebih lanjut, agar memudahkan pelari saat beraktifitas.

\section{UCAPAN TERIMA KASIH}

Penelitian ini didanai oleh DIKTI dengan skema Penelitian Dosen Pemula (PDP) tahun 2018 berdasarkan Surat Keputusan Nomor 3/E/KPT/2018 dan Perjanjian Kontrak Nomor 120/SP2H/LT/DRPM/2018.

Selain itu, Team Peneliti mengucapkan terimakasih kepada seluruh pihak yang telah membantu pengambilan data di tempat Fitness Urban Gunawangsa Mer Lantai 5 (Jln Raya Kedung Baruk No.96 Rungkut, Surabaya, Jawa Timur).

\section{DAFTAR PUSTAKA}

Achten, J. (2003). Heart Rate Monitoring Application and Limitations. Adis Data Information, 517-533.
Camarda, sergio R. de A. (2008). Comparison of Maximal Heart Rate Using predeiction Equations Propsed by Karvonen dan Tanaka. Arq Brass Cardiol.

Febrida, M. (2013). Pelari Jakarta Marathon Meninggal, Diduga kena Serangan Jantung. Retrieved January 13, 2018, from https://www.liputan6.com/health/read/73 0869/pelari-jakarta-marathon-meninggaldiduga-kena-serangan-jantung

Harsono, B., Liman, J., \& Djohan, N. (2017). Rancang Bangun Alat Pemantau Laju Detak Jantung Saat Latihan Fisik. Teknik Dan Ilmu Komputer, 1(4).

Islam, S. M. R., Kwak, D., Kabir, M. D. H., Hossain, M., \& Kwak, K.-S. (2015). The internet of things for health care: a comprehensive survey. IEEE Access, 3, 678-708.

Puspasari, I., Musayyanah, M., \& Susanto, P. (2018). Telereport Target Heart Rate (THR) pada Cardio Exercise Berbasis Metode Karvonen. In Seminar Nasional Aplikasi Teknologi Informasi (SNATI).

Wilkins. (2000). ACSM's guidelines for Exercises Testing and Prescription (6th ed.). Baltimore Lippincoot Wiliam.

Yulian, R., \& Suprianto, B. (2017). Rancang Bangun Photoplethysmography (PPG) Tipe Gelang Tangan untuk Menghitung Detak Jantung Berbasis Arduino. Jurnal Teknik Elektro, $6(3)$. 